\title{
Pemahaman Guru Pendidikan Agama Kristen Tentang II Timotius 3:10 Terhadap Peningkatan Kecerdasan Spiritual Anak Didik
}

\author{
Santy Sahartian \\ 1) Dosen Sekolah Tinggi Teologi Berita Hidup \\ *) Penulis korespondensi: sahartiansanty@gmail.com
}

Received: 8 Dec 2018 / Revised: 22 Dec 2018 / Accepted: 26 Dec 2018

\begin{abstract}
Abstrak
Guru Pendidikan Agama Kristen adalah seseorang yang profesinya mengajar untuk mendewasakan peserta didik melalui pendidikan yang berisi ajaran kekristenan dengan menekankan ketiga aspek (kognitif, afektif dan psikomotorik) berdasarkan iman kristen. Kecerdasan spiritual merupakan kecerdasan yang tertinggi yang dimiliki oleh seseorang untuk mengerti dan memahami keberadaannya, yang dinilai sebagai tingkat kerohanian seseorang dalam hubungannya dengan Tuhannya. pembentukan kecerdasan spiritual anak didik adalah suatu proses untuk membentuk kehidupan rohani anak didik sehingga ia memiliki kecakapan untuk merealisasikan kebenaran Firman Tuhan dalam kehidupan sehari-harinya. Sebagai seorang guru pendidikan Agama Kristen mempunyai peran yang sangat penting dalam mengerti akan kepribadian anak didiknya. Guru

Pendidikan Agama Kristen mempunyai pengaruh yang sangat penting, seperti yang Alkitab katakan seorang Guru haruslah cakap di dalam mengajar penulis akan memaparkan tentang pemahaman guru tentang II Timotius 3:10. Guru Pendidikan Agama Kristen sebagai pendidik anak didik atas dasar tanggung jawab dan kasih sayang serta keiklasan guru. Dalam hal ini guru Agama Kristen mempunyai peran
\end{abstract}


yang sangat penting bagi anak didik dalam mempelajari, mengkaji, mendidik dan membina kehidupannya dalam kebenaran. Sehingga guru PAK dapat melihat apa yang dihasilkan ketika mereka mendidik anak didik dengan pemahaman yang benar tentang prinsip-prinsip PAK yang terdapat di II Timotius 3:10. Sangatlah penting seorang anak mempunyai kecerdasan spiritual. Tetapi tidak hanya sekedar anak mempunyai kecerdasan tersebut, tetapi perlu adanya peningkatan. Peningkatan ini berfungsi supaya kecerdasan dalam pribadi anak lebih sempurna. Meningkatkan kecerdasan spiritual juga dapat membuat anak melihat sesuatu yang lebih terang dan humoris, meraih kegembiraan dan mempunyai kegigihan. Ada dua hal yang bisa dilakukan untuk meningkatkan kecerdasan Spiritual, baik secara rohani maupun secara umum.

Kata Kunci: Guru Pendidikan Agama Kristen, Kecerdasan Spiritual

\begin{abstract}
Christian Religious Education Teacher is someone whose profession teaches to mature students through education that contains the teachings of Christianity by emphasizing the three aspects (cognitive, affective and psychomotor) based on Christian faith. Spiritual intelligence is the highest intelligence possessed by a person to understand and understand its existence, which is assessed as a level of spirituality of a person in relation to his God. the formation of students' spiritual intelligence is a process to shape the spiritual life of students so that they have the ability to realize the truth of God's Word in their daily lives. As a teacher of Christian Religion education has a very important role in understanding the personality of their students. The Christian Religious Education teacher has a very important influence, as the Bible says a teacher must be capable of teaching the researcher will explain the teacher's understanding of II Timothy 3:10 .

Christian Religious Education Teachers as student educators on the basis of responsibility and affection and teacher skills. In this case the Christian Religion teacher has a very important role for students in
\end{abstract}


learning, studying, educating and fostering their lives in truth. So that PAK teachers can see what is produced when they educate students with a correct understanding of the PAK principles found in II Timothy 3:10. It is very important that a child has spiritual intelligence. But not only children have intelligence, but need improvement. This improvement functions so that the intelligence in the child's personality is more perfect. Increasing spiritual intelligence can also make children see something that is brighter and humorous, achieve excitement and have perseverance. There are two things that can be done to improve Spiritual intelligence, both spiritually and in general.

Keywords: Christian Religion Education Teacher, Spiritual Intelligence

\section{Pendahuluan}

Guru Pendidikan Agama Kristen juga berpengaruh sangat besar dalam keberhasilan anak didik. Tidak hanya dalam kecerdasan intelektual, kecerdasan emosi tetapi yang lebih penting adalah dalam kecerdasan spiritual anak didik. Peran guru Pendidikan Agama Kristen sangatlah dibutuhkan dalam proses belajar mengajar, terlebih dalam hal kerohanian. Pelaksanaan belajar mengajar selayaknya berpegang kepada apa yang tertuang dalam perencanaan mengajar. Guru hendaklah mempunyai kepekaan di dalam menghadapi situasi yang dialami oleh anak didiknya, sehingga proses belajar dan mengajar dapat berjalan dengan baik dan apa yang diharapkan dapat tercapai. Oleh sebab itu peneliti akan membahas lebih jelas lagi bagaimana Peranan Pemahaman Guru Pendidikan Agama Kristen Tentang II Timotius 3:10 Terhadap Peningkatan Kecerdasan Spiritual Anak didik. Dimana beberapa guru yang tidak memperhatikan bagaimana perkembangan anak didik dalam hal Kecerdasan Spiritual. Hal ini dikarenakan masih kurangnya pemahaman guru akan prinsip yang harus dipahami oleh guru. Dewasa ini pentingnya peranan dan fungsi dari seorang guru, terlebih Guru Pendidikan Agama Kristen telah dipahami oleh beberapa pihak terutama dalam pendidikan. 
Dalam hal ini seorang Guru Pendidikan Agama Kristen juga dikatakan telah melaksanakan Amanat Agung, sebagaimana telah dituliskan di dalam Alkitab (Mat. 28:20) "dan ajarlah mereka melakukan segala sesuatu yang telah Kuperintahkan kepadamu.” Dari pengertian di atas peneliti berpendapat bahwa pengaruh adalah suatu daya tindakan yang berikan oleh seseorang (guru) baik secara individual maupun secara bersama-sama yang dapat membentuk suatu watak dan kepercayaan akan anak didik. Guru merupakan salah satu faktor penentu tinggi rendahnya mutu pendidikan. Keberhasilan penyelenggaraan pendidikan sangat ditentukan oleh sejauh mana kesiapan guru dalam mempersiapkan peserta didiknya melalui kegiatan belajar mengajar. ${ }^{1}$ tujuan dari penulis adalah untuk menjelaskan maksud dari pemahaman Guru Pendidikan Agama Kristen tentang II Timotius 3:10, menjelskan yang dimaksud dengan kecerdasan spiritual anak didik dan menemukan pengaruh pemahaman Guru Pendidikan Agama Kristen tentang II Timotius 3:10 terhadap peningkatan kecerdasan spiritual anak didik.

\section{Guru Pendidikan Agama Kristen}

Dalam pengertian umum pengertian guru menurut Kamus Besar Bahasa Indonesia, adalah "orang yang pekerjaannya atau mata pencahariannya atau profesinya adalah mengajar."2 Sedangkan menurut John.M.Nainggolan pengertian guru Kristen adalah "orang yang memberi dirinya secara penuh kepada Yesus Kristus, percaya dan menyambut sepenuhnya kedudukan dan peran Yesus sebagai Tuhan, Juruselamat dan Raja atas kehidupannya."

Pendidikan adalah usaha sadar atau kegiatan yang dilakukan oleh seseorang terhadap atau kepada orang lain untuk mencapai suatu tujuan yang diharapkan. Banyak sekali pengertian mengenai pendidikan itu sendiri, karena secara umum pendidikan sulit untuk didefinisikan.

\footnotetext{
${ }^{1}$ Jonh M. Nainggolan. 2006. Menjadi Guru Agama Kristen. (Bandung: Generasi Info Media), 26

${ }^{2}$ Pusat Bahasa Departemen Pendidikan Nasional. 2011. Kamus Besar Bahasa Indonesia, edisi 3 (Jakarta: Balai Pustaka), 312.

${ }^{3}$ Jonh M. Nainggolan. 2007. Menjadi Guru Agama Kristen, (Bandung: Generasi Info Media), 3
} 
Pendidikan dalam Kamus Besar adalah "sebuah proses pengembangan sikap dan tata laku seseorang (kelompok) dalam mendewasakan manusia melalui upaya pengajaran dan pelatihan." Agama Kristen adalah "sebuah ajaran atau system yang mengatur tata keimanan dan peribadatan kepada Tuhan yang maha kuasa (Yesus Kristus), serta kaidah yang berhubungan dengan pergaulan serta lingkungannya.",

Hardi Budiyana berpendapat pendidikan Agama Kristen adalah "pendidikan yang berisi ajaran-ajaran kekristenan dengan menekankan ketiga aspek pendidikan yaitu pengetahuan (kognitif), sikap dan nilainilai (afektif), dan ketrampilan (psikomotorik) yang berdasarkan iman Kristen."

Jadi seorang guru pendidikan Agama Kristen adalah seseorang yang profesinya mengajar untuk mendewasakan orang lain melalui pendidikan yang berisi ajaran kekristenan dengan menekankan ketiga aspek (kognitif, afektif dan psikomotorik) berdasarkan iman kristen.

Seorang guru Pendidikan Agama Kristen harus mempunyai visi untuk mengarahkan tujuan hidupnya, dalam mengajar juga harus berdasarkan pada Alkitab dan menjadikan Kristus sebagai pusat beritanya. Seperti yang dikatakan John Nainggolan "seorang guru PAK haruslah memahami pribadi Yesus sebagai guru yang harus diteladaninya dalam hidupnya dan dalam melaksanakan tugasnya sebagai guru."

Hal ini dikarenakan bahwa tujuan pendidikan Agama Kristen adalah menjadikan anak didik atau murid bertambah dewasa rohani berdasarkan Firman Tuhan. Guru harus mempunyai keyakinan dan ketegasan bahwa ada kebutuhan rohani dalam diri seorang anak didik. Guru juga harus memahami dan mengenal setiap apa yang menjadi kebutuhan anak didik. Dengan hal inilah maka perilaku pendidikan dari upaya guru agama sangat kompleks, yang membutuhkan kajian secara

\footnotetext{
${ }^{4}$ WJS. Poerwodarminto. 1984. Kamus Umum Bahasa Indonesia, (Jakarta: PN Balai Pustaka), 34.

${ }^{5}$ Soetomo. 1993. Dasar-dasar Interaksi Belajar Mengajar, (Surabaya: Usaha Nasional), 273

${ }^{6}$ Hardi Budiyana. 2011. Dasar-dasar Pendidikan Agama Kristen, (Solo: Berita Hidup Seminary), 4.
} 
mendalam. Dalam pendidikan secara umum dapat dikatakan bahwa perilaku guru agama dipandang sebagai sumber pengaruh sedangkan tingkah laku anak didik sebagai efek dari berbagai proses tingkah laku dari kegiatan interaksi dalam kehidupan.

\section{Pemahaman Guru Pendidikan Agama Kristen Tentang II Timotius} 3:10

Guru Pendidikan Agama Kristen mempunyai pengaruh yang sangat penting, seperti yang Alkitab katakan seorang Guru haruslah cakap di dalam mengajar (II Timotius 3:10). "Tetapi engkau telah mengikuti ajaranku, cara hidupku, pendirianku, imanku, kasihku, dan ketekunanku."

Ajaran

Kata Yunani yang digunakan pada kata "ajaranku" adalah "didaskalia" (didaskalia) "teaching" kata ini berasal dari kata "didaskaloj" yang berarti "guru", juga dalam Terjemahan Baru adalah mengajar, ajaran-ajaran, ajaranku. Ajaranku diterjemahkan "Semua orang Yahudi mengetahui jalan hidupku sejak masa mudaku" (Kis 26:4). ${ }^{7}$ "Ajaran adalah suatu pemahaman (yang biasanya menyangkut konsep kehidupan) yang disampaikan kepada pihak yang lebih luas dengan sengaja dan terencana." "Jadi istilah "ajaranku" yang dimaksudkan Paulus di sini adalah iman yang benar, yang lahir dari Injil Kristus. Paulus bukan ingin menonjolkan diri namun ia ingin menunjukkan kepada Timotius keteladanan apa yang diajarkannya. Paulus juga ingin supaya semua orang mengerti atau mengetahui jalan hidupnya.

Dengan pengajaran yang diberikan oleh guru anak akan mendapatkan atau menemukan dan mengembangkan kompetensinya. Seperti yang dimaksudkan Paulus dalam ayat 10 dimana pengajaran yang guru berikan harus sampai kepada anak didik. Di tengah-tengah kemajuan zaman baik teknologi maupun pendidikan, guru harus berpengaruh besar untuk bisa membawa anak mengerti dengan apa yang diajarkannya.

\footnotetext{
${ }^{7}$ Kubo, Greek-English Lexicon, 214.
} 
Ajaran yang diberikan oleh guru Pendidikan Agama Kristen haruslah selalu berdasarkan kepada kebenaran Firman Tuhan, karena Alkitab menjelaskan bahwa "Segala tulisan yang diilhamkan Allah memang bermanfaat untuk mengajar, untuk menyatakan kesalahan, untuk memperbaiki kelakuan dan untuk mendidik orang dalam kebenaran.", Guru tidak boleh jemu-jemu dalam mengajar anak didik, tetapi secara terus menerus sampai anak didik mengerti. Ajaran itu sendiri tidak hanya berlaku untuk anak didik saja, tetapi sebelum guru mengajarkan apa yang akan diajarkan terlebih dahulu guru harus memahami apa yang akan diajarkannya.

\section{Cara Hidup}

"Cara hidupku" kata yang dipakai dalam bahasa Yunani "agoge" berasal dari kata dasar "agw" yang mempunyai definisi "cara hidup". Dalam hal ini Paulus memberikan pandangan bahwa hidup Paulus berpegang kepada kebenaran di saat masa-masa krisis. Sekalipun Paulus ditinggalkan oleh teman-teman sekerjanya. "Bagi Paulus ajaran yang benar adalah harus nampak di dalam cara hidup yang baik (taf 1 Tim 1:19)." Paulus memberitakan tentang persembahan bukan dengan memperlihatkan kehidupan yang mewah. "Bagi Paulus ajaran yang benar harus nampak di dalam cara hidup yang baik." orang lain jauh lebih banyak dari pada yang diterimanya dari jemaat. "Paulus membuktikan bahwa dirinya adalah seorang hamba bukan mencari nama." Dan Paulus juga menginginkan supaya Timotius terus berpadanan dengan apa yang Paulus mengajarkan melalui cara hidupnya. Sehingga Timotius dapat mengerti apa yang harus.

Apa yang dihidupi oleh seorang guru, terutama guru Agama Kristen akan disalurkan secara tidak langsung kepada murid atau anak didik yang dididik. Sehingga cara hidup yang positiflah yang diberikan

\footnotetext{
${ }^{8}$ Alkitab. 2 Timotius 3:16

${ }^{9}$ R Budiman. 1984. Tafsiran Alkitab Surat-surat Pastoral I dan II Timotius
} dan Titus. (Jakarta: BPK Gunung Mulia), 105.

${ }^{10}$ Budiman. 2008. Taf. Alk. Surat-surat Pastoral I \& II Timotius Dan Titus. (Jakarta: BPK Gunung Mulia), 105. 
kepada murid yang ada. Hal ini yang menuntut seorang guru Agama Kristen harus sudah lahir baru.

\section{Pendirian}

Pendirianku dalam bahasa Yunaninya “proqesij"(prothesis) purpose berasal dari kata "protithemai" yang berarti "kesetiaan". Dalam Terjemahan Baru diartikan dengan "maksud, rencanaku, pendirianku" yang berarti rencana, tujuan, keinginan, kesetiaan. Yang dimaksudkan adalah "Motivasi terdalam dari pelayanan Paulus. Ia tidak mementingkan diri sendiri, melainkan kepentingan orang lain (bdk 1 Kor 9: 22)." Dalam hal ini Paulus menginginkan Timotius untuk terus setia di dalam pelayanannya. "Kita yang setia kepada Tuhan Yesus dan kepada InjilNya, juga seharusnya rela menderita bagi Kristus. Tidak ada jalan untuk menghindari itu."11 "Timotius harus bertahan dalam penderitaan seperti yang telah dilakukan oleh Paulus yang sedang dipersembahkan sebagai korban."12 Maksud Paulus adalah bahwa Timotius harus tetap menjalankan pelayanannya dengan keadaan yang tidak mungkin sekalipun. Jadi bagi Paulus bahwa mempunyai pendirian itu sangatlah penting supaya tidak mudah tergoyahkan.

Dalam dunia pendidikan seorang guru agama juga perlu mempunyai pendirian yang kokoh. Pendirian yang kokoh di sini bahwa seorang guru harus setia dalam pelayanannya. Karena tidak hanya memberikan pengajaran semata, melainkan dengan penuh kesetiaan dengan apa saja yang harus dijalani. Kesetiaan ini juga yang harus guru berikan kepada anak didik. Seseorang yang memiliki pendirian akan mempunyai rasa percaya diri dalam dirinya. Rasa percaya diri merupakan hal yang sangat penting dalam kehidupan semua orang. Percaya diri tidak begitu saja melekat pada diri anak, bukan juga merupakan bawaan dari lahir atau keturunan. Seperti yang diungkapkan oleh Hendra Surya bahwa: "Terbentuknya kemampuan percaya diri adalah suatu proses

${ }^{11}$ J. Wesley Brill. t.th. Tafsiran Surat Timotius dan Titus. (Bandung: Yayasan Kalam Hidup), 79.

${ }^{12}$ Willy Marxsen. 1968. Pengantar Perjanjian Baru. (Jakarta: BPK Gunung Mulia), 282. 
belajar bagaimana merespon berbagai rangsangan dari luar dirinya melalui interaksi dengan lingkungannya." 13

Untuk itulah seorang guru Agama Kristen harus memahami masalah kejiwaan yang menghambat terbentuknya percaya diri pada anak, sehingga dapat menentukan tindakan yang harus dilakukan guru untuk menumbuhkan rasa percaya diri pada anak. Karena anak yang percaya diri dalam hal apapun akan mengandalkan diri sendiri bukan orang lain. Di sini juga peran guru diuji dalam kesetiaannya membimbing anak sampai anak dapat memiliki rasa percaya diri dalam dirinya.

\section{Iman}

Kata "imanku" ketika dilihat dalam bahasa yunaninya adalah "pistij" (pistis) berasal dari kata "peitho" yang berarti keyakinan. Di samping itu didefinisikan sebagai iman, imanmu, kepercayaan, percaya.

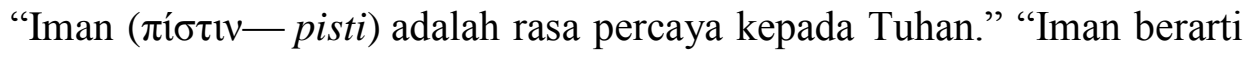
kesetiaan kepada tugas, atau ikatan pribadi dengan Yesus (3:15)." Menurut Alkitab iman merupakan "dasar dari segala sesuatu yang kita harapkan dan bukti dari segala sesuatu yang tidak kita lihat." $"$ Timotius tidak hanya ikut serta dalam setiap rute perjalanan Paulus, tetapi ia juga bersedia dididik oleh Paulus dalam iman dan pengabdian terhadap tugas pelayanan jemaat. Ini diartikan sebagai seseorang yang harus percaya bahwa Allah akan memenuhi kebutuhan setiap orang yang percaya dengan sungguh-sungguh berharap kepada Tuhan. Karena dengan iman yang kuat maka keajaiban Allah akan dnyatakan kepada yang berpengharapan kepadaNya.

Maksud Paulus dalam hal ini bahwa akan banyak terjadi kesulitan yang harus dihadapai di dalam pelayanan, dan sikap yang harus diambil oleh Timotius adalah harus mempunyai iman (rasa percaya dan yakin) di dalam Tuhan dan Tuhan akan menolong. karena Paulus percaya akan pertolongan Tuhan kepada orang-orang yang percaya kepadaNya.

\footnotetext{
${ }^{13}$ Hendra Surya. 2007. Percaya Diri Itu Penting. (Jakarta: Pt Elex Media Komputindo), 2.

${ }_{15}^{14}$ Dianne Bergant. 2002. Tafsir Perjanjian Baru. (Yogyakarta: Kanisius), 399.

${ }^{15}$ Alkitab, Ibrani 11:1
} 
Seorang guru PAK harus mempunyai iman yang kuat seperti apa yang dikatakan Paulus kepada Timotius. Rasa percaya dan keyakinan yang kuat harus dimiliki oleh guru, karena di dalam panggilannya terutama dalam proses belajar mengajar akan banyak sekali hal yang harus dihadapi seorang guru. Baik dari sisi anak didik tetapi juga dari rekan sekerja. Salah satu ciri orang yang tidak mempunyai iman adalah khawatir akan apa yang terjadi.

Untuk itulah iman yang kuat harus selalu dimiliki secara penuh. Di dalam mengajar guru juga harus mempunyai iman bahwa apa yang diajarkan akan dapat diterapkan dalam kehidupan anak didik. Yang paling utama dalam tugas seorang guru untuk mendidik anak adalah melibatkan Tuhan di dalamnnya. Karena apabila guru melibatkan Tuhan dalam setiap apa yang dilakukan maka akan tercapai pembelajaran yang diberikan sampai dengan hasil yang memuaskan.

\section{Kesabaran}

Kata "sabar" dalam bahasa Yunaninya adalah "makroqumia" (makrothumia) yang berasal dari kata "makrothumos" yang berarti "ketahanan". Dalam Terjemahan Baru kesabaran, sabar, kesabaranku. Inilah sifat Paulus ketika bertahan dari serangan-serangan orang lain yang menentang dan menganiaya. "Kesabaran adalah ketenangan, keramahan, dan keteguhan Paulus dalam prinsip terutama dalam menghadapi tantangan dan situasi sulit." "Kesabaran juga merupakan sikap tahan menderita bersama orang lain, tidak peduli betapa tidak masuk akalnya mereka atau betapa menyenangkannya mereka dan betapa sulit diaturnya mereka."17 "Panjang sabar terhadap orang-orang yang menganiayanya dan menentang dia." Hanya sikap yang sabar yang ia (Paulus) tunjukkan kepada orang yang menganiaya. Paulus juga bertujuan untuk menasihati Timotius supaya mempunyai ketabahan ketika menghadapi segala sesuatu dalam pelayanan yang dilakukan.

${ }^{16}$ Surip Stanislaus. 2010. Bimbing Anak Cinta Alkitab. (Yogyakarta: Kanisius), 52.

${ }^{17}$ John Drescher. 1993. Melakukan Buah Roh (Jakarta: BPK Gunung Mulia), 183. 
Demikianlah dalam pelayanan seorang guru terhadap muridmurid yang dipercayakan, sabar merupakan kunci yang harus dimiliki oleh seorang guru. Seperti apa yang dikatakan Paulus kepada Timotius bahwa banyak orang yang menganiaaya dan menolak, sehingga diperlukan kesabaran supaya pelayanan yang dilakukan bisa dilakukan.

Seluruh peserta didik memiliki potensi yang harus dipupuk dan dikembangkan oleh pendidikan di sekolah melalui kegiatan pembelajaran agar mencapai perkembangan yang optimal. Dan sekolah merupakan lembaga formal yang diberikan tanggung jawab untuk meningkatkan perkembangan peserta didik termasuk perkembangan intelektualnya. Di sisnilah peran seorang guru khususnya Pendidikan Agama Kristen harus penuh kesabaran dalam menumbuhkan kecerdasan dalam diri anak didik.

\section{Kasih}

Di samping kelima hal itu yang harus diketahui bahwa Paulus adalah seorang yang penuh dengan kasih. Kata "kasihku" dalam bahasa Yunaninya "agape" (agape) love dan "murah hati" berasal dari kata "agapao" yang diartikan sebagai "mencintai" dan juga sebagai yang secara sukarela menyerahkan dirinya untuk melayani orang lain. "Kasih berarti komitmen yaitu penyerahan diri seutuhnya kepada orang lain dan kasih itu bertindak tanpa hubungan dengan apa yang kita rasakan atau tidak kita rasakan." ${ }^{18}$ Di dalam Terjemahan baru adalah kasih, kasihmu, mengasihi, kasihku.

Seperti halnya Allah telah memberikan kasih (Agape) kepada manusia sehingga Dia memberikan nyawaNya. Seperti yang tertulis dalam Yohanes 3:16 "Karena begitu besar kasih Allah akan dunia ini, sehingga Ia telah mengaruniakan anakNya yang tunggal, supaya setiap orang yang percaya kepadaNya tidak binasa melainkan beroleh hidup yang kekal. ${ }^{, 19}$ Kasih juga menerima orang lain sebagaimana adanya demi Yesus. Maksud dari Paulus dalam pengertian ini adalah dimana Timotius harus mempunyai kasih, terutama kasih agape yang menerima setiap

${ }^{18}$ Jerry Cook. 1990. Kasih Penerimaan dan Pengampunan dalam Jemaat (Jakarta: BPK Gunung Mulia), 6

${ }^{19}$ Alkitab LAI, Yohanes 3:16 
orang dalam pelayanannya. Jadi yang Paulus inginkan dari Timotius adalah Timotius harus mempunyai kasih yang telah diajarkan melalui kehidupan Paulus.

Dalam proses belajar mengajar guru juga seperti yang Paulus harapkan kepada Timotius. Guru harus mempunyai kasih dalam mendidik anak dalam kebenaran. Mendidik anak untuk menjadi seorang yang dewasa dalam Kristus tidaklah mudah, apa yang diajarkan haruslah sesuai dengan apa yang dihidupi guru. Karena figur seorang guru yang baik dan penuh kasih juga sangat diperlukan. Seperti yang Ir. Jarot Wijanarko katakan bahwa "mendidik adalah menyampaikan pengajaraan, norma-norma, dan nilai-nilai hidup, aturan dan hukum sesuai dengan agama yang dianut sebagai sumber ajaran. ${ }^{, 20}$

Secara tidak langsung apa yang ada di dalam pribadi seorang guru akan masuk kepada pribadi anak didik. Seperti yang diungkapkan oleh Sadirman "Mendidik berarti mentransfer nilai-nilai kepada anak didik.Nilai-nilai tersebut harus diwujudkan dalam tingkah laku seharihari." 21

Dalam mendidik anak, guru juga berperan sebagai seorang teman yang mampu membawa anak didik untuk mempunyai kecerdasan dengan kasih. Seorang guru dalam mendidik anak dianjurkan untuk tidak memiliki rasa cepat puas dengan keadaan anak. Tetapi hendaklah terus mendidik anak untuk berkembang lebih jauh dan dapat mencapai suatu kesempurnaan. Karena seperti sifat kasih sendiri adalah sabar, murah hati, sabar menanggung segala sesuatu dan juga kasih tidak pemarah.

\section{Ketekunan}

Kata ketekunanku dalam bahasa Yunani adalah "u'pomonh" (hupomone) berasal dari kata "hupomeno" yang diartikan "bertahan". Yang didefinisikan dalam terjemahan baru merupakan ketekunan, tekun, kesabaran , ketekunanmu, ketabahan , sabar , bertahan , ketekunanku , menahan dengan penuh kesabaran, ketabahanmu. "Ketekunan

\footnotetext{
${ }^{20}$ Jarot Wijanarko. 2005. Mendidik Anak untuk Meningkatkan EQ dan $S Q$,(Jakarta: Gramedia Pustaka Utama), 3.

${ }^{21}$ Surdiman A.M. 1996. ,Interaksi dan Motivasi Belajar Mengajar, (Jakarta: PT Raja Grafindo Persada), 135.
} 
merupakan sebuah kunci menggapai kesuksesan."22 Ketekunan juga merupakan kegigihan dan Paulus dalam menghadapi kesulitan-kesulitan hidup. Di samping itu ketekunan juga dapat diartikan sebagai "Tekun adalah keputusan atau ketetapan hati yang kuat (teguh) untuk bersungguh-sungguh, rajin, dan tuntas dalam melakukan apa pun." Untuk menegaskan apa yang dikatakan Paulus dalam kata ini bahwa setiap pengikut Kristus akan mendapat penganiayaan. Seperti halnya dikatakan dalam 2 Tim 3:12 "Memang setiap orang yang mau beribadat kepada Kristus Yesus akan menderita penganiayaan."

Seorang guru harus mempunyai sifat yang tekun dalam mendidik dan membimbing anak didik. "Sifat adalah karakteristik psikologis yang berasal dari dalam diri seseorang." Ketekunan yang dimiliki seorang Paulus patutlah dicontoh sebagai dasar seorang guru dalam mendidik anak didik. Dengan ketekunan yang dimiliki guru, tidak menutup kemungkinan sifat tekun ini juga akan dimiliki oleh anak didik. Tanpa sifat yang tekun dan ulet guru akan kesulitan dalam mencapai tujuan pembelajaran yang maksimal. Karena ketekunan itu merupakan kunci dari keberhasilan.

Guru berperan sebagai sarana untuk pembentukan karakter seorang anak. Tidak hanya sekedar membimbing tetapi dalam membimbing membutuhkan ketekunan, terutama dalam pembentukan karakter anak didik.

Dengan ketekunan guru akan bekerja dengan penuh keyakinan, akan memperoleh keberhasilan, apa yang dilakukan dapat dipertanggungjawabkan dengan profesional bahkan dengan ketekunan keberhasilan mengajar akan diperoleh guru. Sifat inilah yang harus diberikan guru kepada anak didik, dalam belajar anak juga memerlukan ketekunan sehingga hasil yang dicapai juga akan maksimal.

\section{Kebenaran}

Kata "kebenaran" dalam ayat 14 merupakan diakaiosune (diakaiosune). "Tetapi hendaklah engkau tetap berpegang pada kebenaran

${ }^{22}$ Hagar Pangarep. 2010. 101 tips Kilat Personality Plus. (Yogyakarta: Media Pressindo), 127 
yang telah engkau terima dan engkau yakini, dan selalu mengingat orang yang selalu mengajarkannya kepadamu" (2 tim 3:14). "Pada Paulus kebenaran itu tidak sekadar perilaku benar di hadapan Allah, tetapi suatu hubungan yang benar dengan Allah." Jadi maksud Paulus dalam kata ini adalah bahwa Timotius harus tetap berpegang kepada kebenaran yang telah ia terima dan yakini. Dimana ia harus secara terus menerus meneruskan segala sesuatu yang telah ia pelajari. Tugas Timotius harus membawa para lawannya kepada jalan yang benar. Yang mana Timotius harus menyatakan kesalahan, menegur dan menasehati dengan penuh kesabaran.

Bagi seorang guru selain mengajar dan mendidik adalah melatih atau membimbing anak didik dan mempersiapkan anak didik sebagai pribadi yang siap dalam situasi apapun. Dalam hal ini membimbing merupakan sebuah kegiatan untuk menuntun anak didik ke dalam kebenaran. Membimbing dalam arti menuntun sesuai dengan kaidah yang baik dan mengarahkan perembangan anak didik sesuai dengan tujuan dan yang dicita-citakan, termaksud dalam hal ini yang penting ikut memecahkan persoalan-persoalan atau kesulitan yang dihadapi anak didik. $^{23}$

Guru Pendidikan Agama Kristen sebagai pembimbing rohani anak didik atas dasar tanggung jawab dan kasih sayang serta keiklasan guru. Dalam hal ini guru Agama Kristen mempunyai peran yang sangat penting bagi anak didik dalam mempelajari, mengkaji, mendidik dan membina kehidupannya dalam kebenaran. Banyak sekali nilai-nilai moral yang mulia yang diajarkan dalam kekristenan yang harus diajarkan kepada anak didik, antara lain: a) Rendah hati, yaitu sikap yang tumbuh untuk menyadari bahwa segala kemuliaan yang di alam semesta ini adalah murni milik Allah. Bukan kemanusiaan yang ditunjukkan. b) Berfikir positif, dimana seseorang senantiasa berprasangka baik kepada siapapun, dalam kondisi apapun, dan dalam situasi apapun. Walaupun sesuatu itubelum pasti kejelasannya. c) Jujur, sikap ini sangat perlu dimiliki oleh

${ }^{23}$ Pusat Bahasa Departemen Pendidikan Nasional. 2011. Kamus Besar Bahasa Indonesia edisi 3, (Jakarta: Balai Pustaka), 138. 
seorag murid, khususnya sebagai murid Kristus. Jujur adalah sikap apa adanya, tidak mengada-ada dan menunjukkan apa yang memang sebenarnya terjadi. Dalam buku yang berjudul "Three keys to maximize leadership in you" mengatakan bahwa "kejujuran sering diidentikkan dengan integritas."

1. Teladan, dalam hal ini teladan adalah dimana seseorang dapat dipercaya untuk menjadi figur yang dapat memberikan suatu yang positif kepada orang lain dalam segala hal, terutama dari ucapan, tingkah laku maupun dalam kesetiaan kepada Tuhan.

2. Bersyukur, yakni senantiasa berterimakasih kepada Allah, baik secara lisan dan dibuktikan dalam perbuatan dalam menerima karunia itu. Hal ini juga yang selalu Tuhan perintahkan kepada setiap orang yang percaya epadaNya. "Mengucap syukurlah dalam segala hal sebab itulah yang dikehendaki Allah di dalam Yesus Kristus bagi kamu (1 Tesalonika 5:18)., ${ }^{24}$

Kebenaran yang dimaksudkan adalah kebenaran yang sesuai dengan Firman Tuhan. "Dasar FirmanMu adalah kebenaran dan segala hukum-hukumMu yang adil adalah untuk selama-lamanya."25 Jadi apapun yang diajarkan apabila sesuai dengan kebenaran Firman Tuhan adalah benar. Seorang guru Pendidikan Agama Kristen tidak boleh lepas dari Firman Tuhan dalam hidupnya. Guru dapat menggunakan cara hidupnya untuk mengajar anak dalam kebenaran. Dan pembelajaran yang diharapkan baik oleh guru, orang tua bahkan anak didik sendiri juga dapat tercapai dengan maksimal.

\section{Kecerdasan Spiritual Anak Didik}

Menurut Kamus Besar Bahasa Indonesia pengertian anak didik atau murid adalah "Orang yang sedang berguru (belajar, bersekolah). ${ }^{26}$ Murid atau anak adalah pribadi yang "unik" yang mempunyai potensi dan mengalami proses berkembang. Dalam proses berkembang itu anak

\footnotetext{
${ }^{24}$ Alkitab, LAI.

${ }^{25}$ Mazmur 119:160.

${ }^{26}$ Tim Penyususn Kamus Bahasa. 2001. Kamus Besar Bahasa Indonesia, (Jakart: Balai Pustka), 732.
} 
didik atau murid membutuhkan bantuan yang sifat dan coraknya tidak ditentukan oleh guru tetapi oleh anak itu sendiri, dalam suatu kehidupan bersama dengan individu-individu yang lain." 27

Kecerdasan spiritual merupakan salah satu jenis-jenis intelegensi yang harus dimiliki oleh seorang anak atau anak didik. Kecerdasan spiritual mampu mengoptimalkan kerja kecerdasan yang lain. Individu yang mempunyai kecerdasan spiritual yang tinggi, mampu menyandarkan jiwa sepenuhnya berdasarkan makna yang ia peroleh.

Kecerdasan Spiritual (SQ) adalah kecerdasan untuk menyelesaikan masalah makna dan nilai, kecerdasan untuk memposisikan perilaku dan hidup kita dalam konteks makna yang lebih luas dan kaya, kecerdasan unuk menaksir bahwa suatu tindakan atau jalan hidup tertentu lebih bermakna ketimbang yang lain. Kecedasan Spiritual adalah fondasi yang diperlukan untuk memfungsikan Intelegensi Quontient dan Emosional Quontient secara efektif.Bahkan kecerdasan Spiritual (SQ) adalah kecerdasan tertinggi kita. ${ }^{28}$

Kecerdasan spiritual dibutuhkan oleh setiap individu dalam menjalani kehidupan, termasuk anak-anak dan remaja. Kecerdasan spiritual merupakan inti yang dapat menggerakkan kecerdasan lainnya. Seperti yang dikemukakan oleh Andin Sefrina dimana "kecerdasan spiritual adalah kecerdasan yang benyak berkaitan dengan kemampuan seseorang dalam memahami keberadaan jiwa atau spirit yang ada dalam dirinya, serta hubungannya dengan keberadaannya di dunia." 29

Kecerdasan spiritual merepresentasikan motif dasar individu dalam pencarian makna sebagai makhluk. Kecerdasan spiritual adalah kemampuan untuk memberikan makna spiritual terhadap pemikiran, perilaku, dan kegiatan serta mampu menyinergikan IQ, EQ dan SQ dengan komperhensif. Oleh sebab itu, setiap individu perlu mengembangkan dan meningkatkan kecerdasan spiritual sebagai salah

${ }^{27}$ Zakiah Daradjat, dkk. 1995. Metodik Khusus Pengajaran Agama, (Jakarta: Bumi Aksara), 268

${ }^{28}$ Sukidi. 2002. Mengapa SQ lebih penting dari Pada IQ dan EQ, (jakarta: Gramedia Pustaka Utama), 69

${ }^{29}$ Andin Sefrina. 2013. Deteksi Minat Bakat Anak, (Yogyakarta: Media Pressindo), 158. 
satu kecakapan hidup yang harus dimiliki. Seperti yang dikatakan oleh Danar Zohar:

Kecerdasan Spiritual adalah kecerdasan jiwa, ia adalah kecerdasan yang dapat membantu kita menyembuhkan dan membangun diri kita secara utuh.SQ adalah kecerdasan yang berada di bagian diri yang dalam, berhubungan dengan kearifan di luar ego atau pikiran sadar. ${ }^{30}$

Selanjutnya Tasmara juga mengungkapkan bahwa: Kecerdasan spiritual (rohaniah) merupakan inti dari seluruh kecerdasan yang dimiliki manusia karena kecerdasan tersebut dapat memengaruhi perkembangan beberapa kecerdasan yang lainnya, seperti kecerdasan intlektual, kecerdasan emosional, kecerdasan sosial dan kecerdasan physical. Dalam bagan berikut ini Tasmara mencoba menggambarkan bagaimana peran kecerdasan rohaniah atau kecerdasan spiritual menjadi pusat atau inti dari seluruh kecerdasan yang lainnya:

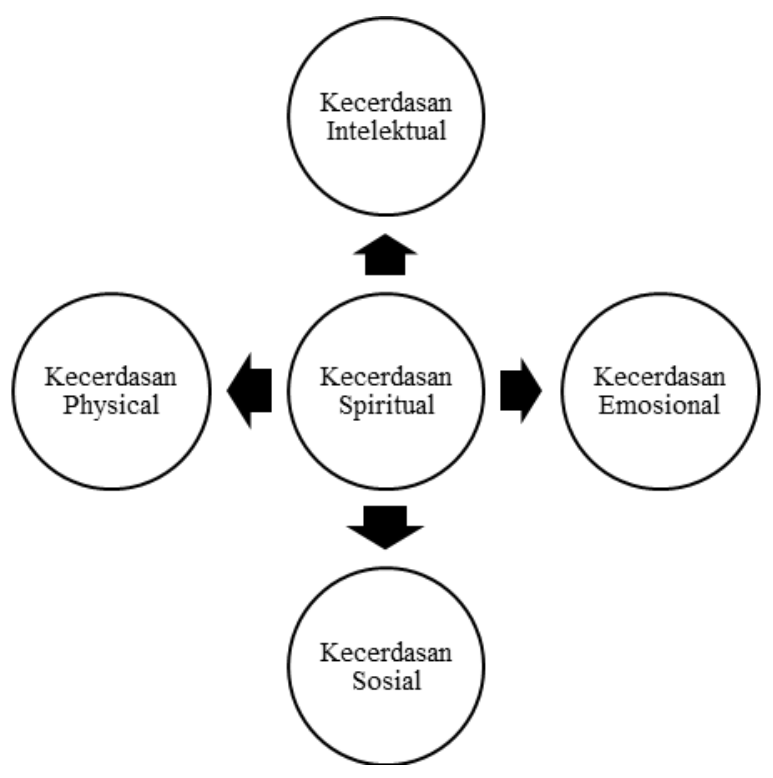

Gambar 1.1 Kecerdasan spiritual menurut Tasmara

${ }^{30}$ Danar Zohar. 2000. Kecerdasan Spiritual. (Bloomsbury: Great Britan), 9 
Kata spiritual (rohani) dalam bahasa Yunaninya adalah pneumatikos, yang berarti bersifat roh atau berkenaan dengan roh. "kata spiritual dalam PB, terutama dalam tulisan Paulus, mempunyai tiga arti, yaitu tentang orang rohani (1 Kor. $2: 13,15 ; 3: 1)$ tentang hal-hal rohani (1 Kor.2:13; 9:11) dan tentang benda-benda rohani, yang merupakan suatu gambaran metafora yang menunuk hal-hal yang spiritual."31 Seseorang yang cerdas dalam spiritual (tingkat kerohanian lebih tinggi) adalah mereka yang telah lahir baru. Jadi dalam kekristenan hidup rohani adalah seseorang yang didiami, dipenuhi dan dikuasai oleh Roh Kudus. Oleh sebab itu orang percaya juga harus mempunyai kecerdasan dalam spiritual. Menurut Yosafat Bangun spiritualitas Kristen adalah "ibadah yang berkaitan dengan hubungan pribadi seorang beriman dengan Allah berdasarkan pengenalan yang benar akan Tuhan secara intim setiap hari dengan Tuhan."32

Dari beberapa penjelasan di atas penulis menyimpulkan bahwa kecerdasan spiritual merupakan kecerdasan yang tertinggi yang dimiliki oleh seseorang untuk mengerti dan memahami keberadaannya. Dipandang dari kekristenan spiritual adalah tingkat kerohanian seseorang dalam ibadahnya kepada Tuhan secara pribadi. Spiritualitas Kristen digunakan untuk mencapai persekutuan yang intim antara orang percaya dengan Allah. Karena kecerdasan spiritual bertindak berdasarkan Roh Kudus. Kecerdasan spiritual juga berkembang bersama fungsi-fungsi kehalusan perasaan (afektif) disertai kejernihan akal budi (kognitif).

Kedua fungsi tersebut mendoronng individu untuk mengalami, mempercayai, bahkan meyakini dan menerima tanpa keraguan tentang adanya kekuatan yang Maha Agung yang melebihi apapun termasuk dirinya. Proses ini yang dimaksud penghayatan keagamaan. Kecerdasan Spiritual memberi kita kemampuan untuk menempatkan diri dan hidup lebih positif dengan penuh kebijaksanaan, kedamaian, dan kebahagiaan yang hakiki.

\footnotetext{
${ }^{31}$ Baker, David L. 1993. Roh dan Kerohanian Dalam Jemaat : Tafsiran Surat I Korintus 12-14, (Jakarta: BPK Gunun Mulia), 34.

${ }^{32}$ Bangun, Yosafat. 2010. Integritas Pemimpin Pastoral, (Yogyakarta: Andi), 27
} 


\section{Peranan Pemahaman Guru Pendidikan Agama Kristen Tentang II Timotius 3:10 Terhadap Peningkatan Kecerdasan Spiritual Anak Didik}

Berikut ini merupakan peranan guru Pendidikan Agama Kristen terhadap pembentukan kecerdasan spiritualitas anak didik :

\section{Anak Didik Mengalami Perjumpaan dengan Kristus}

Selain berperan dalam memenuhi kebutuhan pengetahuan (kognitif), guru Pendidikan Agama Kristen juga berperan dalam memenuhi kebutuhan rohani setiap peserta didik yang dilayaninya, salah satunya yaitu membawa peserta didik mengalami perjumpaan dengan Kristus.

Pengalaman Rasul Paulus dalam Galatia 2:20 yang telah mengalami perjumpaan dengan Tuhan menunjukkan bahwa responsnya terhadap kasih Allah membuatnya menjadi pribadi yang bersaksi dalam tindakan dan kata-kata. Bila seorang guru dapat membawa peserta didik mengalami perjumpaan dengan Kristus, itu berarti ia telah membawa peserta didik memiliki hubungan yang sangat pribadi, mendalam dan dinamis dengan Allah, melalui dan di dalam Yesus Kristus. Dan pada akhirnya anak didik akan memiliki kecerdasan spiritual yang diwujudkannya melalui tutur kata, perilaku, pola pikir dan gaya hidup yang benar dan hidup dalam iman serta ketaatan kepada-Nya.

\section{Anak Didik mengenal Kebenaran Firman Tuhan}

Salah satu peranan guru Pendidikan Agama Kristen terhadap pembentukan kecerdasan spiritual anak didik adalah membawa anak didik kepada pengenalan yang benar akan kebenaran Firman Tuhan. Dalam hal ini "guru Pendidikan Agama Kristen bertindak sebagai penafsir iman Kristen bagi anak didik dalam memahami kebenaran Firman-Nya. "Agar anak didik dapat menerima pesan Alkitab dengan benar, maka penting bagi guru Pendidikan Agama Kristen untuk membekali dirinya dengan berbagai ilmu yang berkaitan dengan teologi, misalnya seperti teologi sistematik, dogmatika, biblika, praktika, historika, dan lain sebagainya." 
Pengenalan yang baik dan benar akan Firman Tuhan akan menolong anak didik bertumbuh secara spiritual. Seringkali guru Pendidikan Agama Kristen mengabaikan hal ini. Mereka cenderung menafsirkan Firman Tuhan dengan konsep pemikirannya sendiri, tanpa memerhatikan langkah-langkah yang harus ditempuh oleh seorang penafsir Firman. Selain membekali dirinya dengan berbagai ilmu yang berkaitan dengan teologi, yang tidak kalah pentingnya bagi guru Pendidikan Agama Kristen adalah mengandalkan urapan dan pimpinan Roh Kudus karena Roh Kuduslah yang akan memampukan dirinya agar dapat memahami kebenaran Firman Allah dengan baik dan benar.

Guru Pendidikan Agama Kristen dapat mengajak anak didik belajar untuk memahami kebenaran FirmanTuhan secara lebih mendalam dalam berbagai kesempatan yang ada, misalnya sebelum proses belajar mengajar dimulai, di tengah-tengah persekutuan doa maupun kelompok tumbuh bersama yang dilaksanakan secara rutin setiap minggunya dan lain sebagainya.

\section{Nilai-Nilai Kristiani Tertanam Kepada Anak Didik}

Guru Pendidikan Agama Kristen memiliki andil yang cukup besar terhadap pembentukan kecerdasan spiritual anak didiknya, salah satunya adalah mengajarkan dan menanamkan nilai-nilai kristiani (spiritual) berdasarkan Alkitab. Diharapkan dengan adanya pengajaran dan penanaman nilai-nilai kristiani, anak didik akan memiliki kecerdasan spiritual. Dewasa ini banyak remaja yang jatuh oleh karena rendahnya tingkat kecerdasan spiritual yang dimilikinya. Oleh sebab itu, guru Pendidikan Agama Kristen perlu untuk memerhatikan hal ini. Dalam Amsal 22:6 dikatakan bahwa "didiklah orang muda menurut jalan yang patut baginya, maka pada masa tuanya pun ia tidak akan menyimpang dari jalan itu." 33

Nilai-nilai kristiani merupakan standar iman yang ditetapkan oleh Allah dalam Alkitab yang harus diwujudkan oleh setiap orang percaya

${ }^{33}$ Alkitab. 2009. Amsal 22:6. (Jakarta: Lembaga Alkitab Indonesia) 
melalui sikap dan tindakan yang nyata dalam kehidupan sehari-harinya (Yakobus 2:17), termasuk peserta didik.

Nilai-nilai kristiani adalah nilai-nilai yang dianut oleh orang Kristen. Sumber nilai-nilai kristiani berasal dari nilai-nilai hidup Yesus Kristus. Nilai-nilai itu pertama kali dianut oleh pengikut-pengikut Yesus sejak awal. Mereka disebut christianoi, Kristen; pertama kali disebut di Antiokhia (Kisah Para Rasul 11:25). Orang Kristen awal meneladani Yesus. Mereka mencontoh dan mengikuti jalan hidup, keteladanan, perkataan, pengajaran, kiprah, sikap hidup, ketaatan, dan kesetiaan Yesus kepada Allah-Nya. Bahkan kematian dan kebangkitan Yesus bagi orang Kristen awal menjadi nilai yang hidup, oleh karena itu mempengaruhi, mendorong, memotivasi, menjadi contoh, teladan, pilihan, dan keyakinan mereka. ${ }^{34}$

Kecerdasan spiritual akan menolong anak didik dalam melewati masa remajanya dengan baik karena anak yang cerdas secara spiritual senantiasa berpegang teguh kepada nilai-nilai spiritual yang telah diajarkan kepadanya." Nilai-nilai kristiani yang harus diajarkan dan ditanamkan oleh guru Pendidikan Agama Kristen kepada peserta didik diantaranya adalah kebenaran, kemurahan, kesetiaan, kebaikan, kasih, kejujuran, kesabaran, kelemahlembutan, dan lain sebagainya.

\section{Anak Didik Termotivasi Melayani dan Menginjil}

Salah satu peranan guru Pendidikan Agama Kristen terhadap pembentukan kecerdasan spiritual adalah memotivasi anak didik untuk melayani dan menginjil. Dewasa ini masih dijumpai banyak dari anak didik (remaja) yang enggan untuk melayani bahkan menginjil. Pdt. Dr. Daniel Nuhamara mengungkapkan bahwa "rendahnya rasa kesadaran dan kepercayaan diri (keberanian) menjadi kendala utama mengapa saat ini remaja sulit untuk melayani dan menginjil." Di sinilah guru Pendidikan Agama Kristen hadir untuk mengubah segalanya. Guru Pendidikan Agama Kristen dituntut untuk dapat menyadarkan dan meyakinkan setiap peserta didik bahwa melayani dan menginjil merupakan tugas utama

${ }^{34}$ Robert R. Boehlke. 1933. Siapa Yesus Sebenarnya? (Jakarta: BPK Gunung Mulia), 20 
setiap orang percaya. Di samping itu, guru Pendidikan Agama Kristen juga dituntut untuk dapat memotivasi anak didiknya agar memiliki kepercayaan dan keberanian diri saat melayani dan menginjil. Bahkan guru Pendidikan Agama Kristen sendiri juga hadir untuk membekali dan melatih anak didiknya dengan berbagai macam keterampilan guna menunjang tugas pelayanan maupun penginjilan yang mereka lakukan.

Anak didik dapat melakukan tugas pelayanan dimulai dari hal yang sederhana, misalnya dengan menjadi pendamping Sekolah Minggu, MC Sekolah Minggu, pengedar kantong kolektan, operator LCD, pemain musik, tamborin, dan lain sebagainya. Dan dengan tindakan yang sederhana pula anak didik dapat melakukan tugasnya sebagai seorang pekabar Injil, misalnya dengan mendoakan teman yang sakit, bersaksi tentang kebaikan Tuhan kepada teman yang belum percaya serta mampu menjadi berkat bagi orang-orang yang ada di sekitarnya (Matius 5:13$15)$.

\section{Anak Didik Mampu Menyelesaikan Persoalan}

Salah satu peranan guru Pendidikan Agama Kristen dalam menunjang pembentukan kecerdasan spiritual adalah membimbing anak didik dalam mengatasi berbagai macam persoalan mengingat remaja mulai diperhadapkan dengan berbagai persoalan yangkian kompleks. Dalam bukunya, B. S. Sidjabat juga mengemukakan bahwa "guru Pendidikan Agama Kristen dituntut untuk menjadi seorang pendamping bagi anak didiknya ketika mereka sedang menghadapi suatu persoalan." Hal ini dimaksudkan agar anak didik tidak keliru dalam mengambil keputusan dalam menyelesaikan setiap persoalan yang sedang mereka hadapi.

Anak didik sangat membutuhkan seseorang yang dapat membimbingnya dalam menghadapi suatu persoalan. Hal ini dikarenakan remaja sendiri belum mampu memiliki pendirian yang kuat (mudah diombang-ambingkan oleh berbagai situasi maupun keadaan). Oleh sebab itu, guru Pendidikan Agama Kristen hadir untuk menuntun serta menolong anak didik dalam mencari jawaban atas persoalan yang sedang mereka hadapi secara kreatif di bawah terang Firman Tuhan. Dalam hal 
ini yang perlu diperhatikan oleh guru Pendidikan Agama Kristen ketika menjadi seorang pendamping bagi anak didiknya adalah merubah pola pikir mereka (main set) saat memandang dan memaknai suatu permasalahan (persoalan). Di lain sisi, guru Pendidikan Agama Kristen dituntut juga untuk dapat memotivasi peserta didiknya agar tidak takut untuk menghadapi suatu persoalan sebab dengan adanya persoalan itulah yang akan membawa mereka semakin bergantung sepenuhnya kepadaNya dan menjadikan dirinya semakin dewasa di dalam Dia. Selain itu, yang tidak kalah pentingnya bagi guru Pendidikan Agama Kristen ketika menjadi seorang pendamping bagi anak didiknya adalah mengajarkan dan menanamkan kepada mereka bahwa setiap persoalan yang mereka hadapi sedikitpun tidak pernah melampaui batas kemampuan dan kekuatannya (1 Korintus 10:13).

\section{Mempunyai Kepribadian yang Menarik}

Anak yang memiliki kecerdasan spiritual tinggi tentunya memiliki kepribadian yang menarik yang senantiasa terpancar melalui kehidupan kesehariannya. Dalam Wikipedia.org istilah kepribadian didefinisikan sebagai "keseluruhan cara seorang individu bereaksi dan berinteraksi dengan individu lain." Kepribadian (personality) bukan sebagai bakat kodrati, melainkan terbentuk oleh proses sosialisasi. Kepribadian merupakan kecenderungan psikologis seseorang untuk melakukan tingkah laku sosial tertentu." 35 Kepribadian adalah sesuatu dari diri seseorang yang lebih bersifat internal namun dapat dilihat dan dirasakan oleh orang lain. Dalam bukunya yang berjudul Pengembangan Kepribadian, Euis Winarti mengungkapkan bahwa"kepribadian seseorang dapat dikatakan menarik jika ia memiliki penampilan yang sopan dan sederhana, tutur kata yang lemah lembut dan tingkah laku yang baik."36 a) Penampilan yang Sopan dan Sederhana. Penampilan menarik yang dimaksud disini bukanlah penampilan yang berlebihan dengan memakai perhiasan, pakaian, atau sepatu yang mahal. Namun,

${ }^{35}$ Sumadi Suryabrata. 2002. Psikologi Kepribadian (Solo: Rajawali Press), 45

${ }^{36}$ Euis Winarti. 2007. Pengembangan Kepribadian (Yogyakarta: Graha Ilmu), 
penampilanyang dimaksud di sini ialah penampilan yang sopan dan sederhana. Anak yang cerdas secara spiritual senantiasa memperhatikan kesederhanaan dalam segala hal, khususnya dalam hal berpakaian dan berpenampilan. Ia berusaha untuk berpenampilan yang sederhana, tidak berlebih-lebihan dan tidak menunjukkan kesombongan. Ia tidak mau mengikuti orang-orang yang mengajak untuk berlebihan dalam berpakaian dan berpenampilan dengan mengikuti mode yang tidak mengenal batasan, seperti yang dilakukan oleh kebanyakan remaja saat ini. "Dewasa ini banyak orang terlalu meributkan tentang penampilan atau hal-hal yang menunjukan ekspresi yang berlebihan tanpa memikirkan esensi dari yang mereka lakukan." Namun anak yang cerdas secara spiritual tahu bagaimana ia harus berpakaian dan berpenampilan yang baik. b) Tutur Kata yang Lemah Lembut. Anak yang cerdas secara spiritual pastilah memiliki kepribadian yang menarik. Hal tersebut dapat ditinjau dari cara bicaranya yang lemah lembut (sopan dan penuh hikmat). Ia tidak berbicara kotor, memaki dan mencela. Ia menyadari bahwa setiap ucapan yang keluar dari mulutnya mampu memberikan pengaruh bagi banyak orang yang berada di sekitarnya. Anak yang cerdas secara spiritual pastilah mampu menjadi berkat dan teladan dalam hal perkataannya (1 Timotius 4:16). c) Tingkah Laku yang Baik. Dalam hidup seseorang pada umumnya, tingkah laku menjadi salah satu sorotan utama bagi banyak orang. "Biasanya pemberian cap atau label kepada seseorang didasarkan pada tingkah laku yang ditunjukkannya secara konstan setiap harinya." ${ }^{\text {37 }}$ Anak yang berkercerdasan spiritual tinggi pastilah memiliki tingkah laku yang baik yang tentunya mencerminkan statusnya sebagai orang percaya (Galatia 5:22-23). Ia dikenal sebagai pribadi yang sopan, jujur, bertanggungjawab, disiplin, suka menolong, ramah, lemah lembut, penuh toleransi, dan lain sebagainya.

${ }^{37}$ Syamsu Yusuf, Psikologi Perkembangan Anak dan Remaja (Bandung: Remaja Rosda Karya, 2007), hal. 143 


\section{Kesimpulan}

Guru pendidikan Agama Kristen adalah seseorang yang profesinya mengajar untuk mendewasakan orang lain melalui pendidikan yang berisi ajaran kekristenan dengan menekankan ketiga aspek (kognitif, afektif dan psikomotorik) berdasarkan iman kristen. Seorang guru Pendidikan Agama Kristen harus mempunyai visi untuk mengarahkan tujuan hidupnya, dalam mengajar juga harus berdasarkan pada Alkitab dan menjadikan Kristus sebagai pusat beritanya. Seperti yang dikatakan John Nainggolan "seorang guru PAK haruslah memahami pribadi Yesus sebagai guru yang harus diteladaninya dalam hidupnya dan dalam melaksanakan tugasnya sebagai guru."Hal ini dikarenakan bahwa tujuan pendidikan Agama Kristen adalah menjadikan anak didik atau murid bertambah dewasa rohani berdasarkan Firman Tuhan.

Guru Pendidikan Agama Kristen mempunyai pengaruh yang sangat penting, seperti yang Alkitab katakan seorang Guru haruslah cakap di dalam mengajar (II Timotius 3:10). "Tetapi engkau telah mengikuti ajaranku, cara hidupku, pendirianku, imanku, kasihku, dan ketekunanku."

Ajaran, cara hidup, pendirian, iman, kasih dan ketekunan yang diberikan oleh guru Pendidikan Agama Kristen haruslah selalu berdasarkan kepada kebenaran Firman Tuhan, karena Alkitab menjelaskan bahwa "Segala tulisan yang diilhamkan Allah memang bermanfaat untuk mengajar, untuk menyatakan kesalahan, untuk memperbaiki kelakuan dan untuk mendidik orang dalam kebenaran. Guru tidak boleh jemu-jemu dalam mengajar anak didik, tetapi secara terus menerus sampai anak didik mengerti. Ajaran itu sendiri tidak hanya berlaku untuk anak didik saja, tetapi sebelum guru mengajarkan apa yang akan diajarkan terlebih dahulu guru harus memahami apa yang akan diajarkannya. Guru Pendidikan Agama Kristen sebagai pembimbing rohani anak didik atas dasar tanggung jawab dan kasih sayang serta keiklasan guru. Dalam hal ini guru Agama Kristen mempunyai peran yang sangat penting bagi anak didik dalam mempelajari, mengkaji, mendidik dan membina kehidupannya dalam kebenaran.

Kecerdasan spiritual merupakan kecerdasan yang tertinggi yang dimiliki oleh seseorang untuk mengerti dan memahami keberadaannya. 
Dipandang dari kekristenan spiritual adalah tingkat kerohanian seseorang dalam ibadahnya kepada Tuhan secara pribadi. Spiritualitas Kristen digunakan untuk mencapai persekutuan yang intim antara orang percaya dengan Allah. Karena kecerdasan spiritual bertindak berdasarkan Roh Kudus. Kecerdasan spiritual juga berkembang bersama fungsi-fungsi kehalusan perasaan (afektif) disertai kejernihan akal budi (kognitif). Kedua fungsi tersebut mendoronng individu untuk mengalami, mempercayai, bahkan meyakini dan menerima tanpa keraguan tentang adanya kekuatan yang Maha Agung yang melebihi apapun termasuk dirinya. Berikut peranan pemahaman guru pendidikan Agama Kristen tentang II Timotius 3:10 terhadap peningkatan kecerdasan spiritual anak didik adalah anak didik mengalami perjumpaan dengan Kristus, mengenal kebenaran Firman Tuhan, nilai-nilai Kristiani tertanam kepada anak didik, anak didik termotivasi melayani dan menginjil, dan anak didik mampu menyelesaikan persoalan.

\section{Keputakaan}

Alkitab. 2009. Jakarta: Lembaga Alkitab Indonesia.

Andin Sefrina. 2013. Deteksi Minat Bakat Anak. Yogyakarta: Media Pressindo, 2013.

Baker, David L. 1993. Roh dan Kerohanian Dalam Jemaat : Tafsiran

Surat I Korintus 12-14. Jakarta: BPK Gunung Mulia.

Bangun, Yosafat. 2010. Integritas Pemimpin Pastoral.Yogyakarta: Andi. Budiman, Taf. Alk. 2008. Surat-surat Pastoral I \& II Timotius Dan Titus. Jakarta: BPK Gunung Mulia.

Danar Zohar. 2000. Kecerdasan Spiritual. Bloomsbury: Great Britan.

Dianne Bergant. 2002. Tafsir Perjanjian Baru. Yogyakarta: Kanisius. R Budiman. 1984. Tafsiran Alkitab Surat-surat Pastoral I dan II

Timotius dan Titus. Jakarta: BPK Gunung Mulia.

Hendra Surya. 2007. Percaya Diri Itu Penting. Jakarta: Pt Elex Media Komputindo. 
Euis Winarti. 2007. Pengembangan Kepribadian. Yogyakarta: Graha Ilmu.

Hagar Pangarep.2010. 101 tips Kilat Personality Plus. Yogyakarta: Media Pressindo.

Hardi Budiyana. 2011. Dasar-dasar Pendidikan Agama Kristen. Solo: Berita Hidup Seminary.

Jarot Wijanarko. 2005. Mendidik Anak untuk Meningkatkan EQ dan SQ,Jakarta: Gramedia Pustaka Utama.

J. Wesley Brill. Tafsiran Surat Timotius dan Titus. Bandung: Yayasan Kalam Hidup.

Jerry Cook. 1990. Kasih Penerimaan dan Pengampunan dalam Jemaat, Jakarta: BPK Gunung Mulia.

John Drescher. 1993. Melakukan Buah Roh. Jakarta: BPK Gunung Mulia. John M. Nainggolan. 2006. Menjadi Guru Agama Kristen,Bandung. Pusat Bahasa Departemen Pendidikan Nasional. 2011. Kamus Besar Bahasa Indonesia edisi 3. Jakarta: Balai Pustaka.

Robert R. Boehlke.1933. Siapa Yesus Sebenarnya?. Jakarta: BPK Gunung Mulia.

Soetomo. 1993. Dasar-dasar Interaksi Belajar Mengajar. Surabaya: Usaha Nasional.

Sukidi. 2002. Mengapa SQ lebih penting dari Pada IQ dan EQ. Jakarta: Gramedia Pustaka Utama.

Sumadi Suryabrata. 2002. Psikologi Kepribadian. Solo: Rajawali Press. Surdiman A.M. 1996. Interaksi dan Motivasi Belajar Mengajar. Jakarta: PT Raja Grafindo Persada.

Surip Stanislaus. 2010. Bimbing Anak Cinta Alkitab. Yogyakarta: Kanisius.

Syamsu Yusuf. 2007. Psikologi Perkembangan Anak dan Remaja. Bandung: Remaja Rosda Karya.

Willy Marxsen. 1968. Pengantar Perjanjian Baru. Jakarta: BPK Gunung Mulia.

WJS. Poerwodarminto. 1984. Kamus Umum Bahasa Indonesi., Jakarta: PN Balai Pustaka. 
Zakiah Daradjat. Dkk. 1995. Metodik Khusus Pengajaran Agama. Jakarta: Bumi Aksara. 